\title{
Analysis for Streptomyces spp. recovered from oil refinery soils to grow on diesel
}

\author{
Ismail M.K. Rudwan Saadoun ${ }^{1 *}$ and Mohammad Turki Alawawdeh²
}

${ }^{1}$ Department of Applied Biology, College of Sciences, University of Sharjah, P.O. Box 27272, Sharjah, UAE. ${ }^{2}$ Department of Applied Biological Sciences, Faculty of Science and Arts, Jordan University of Science and Technology, Ar Ramtha 3030, Ramtha, Jordan.

Email: isaadoun@shariah.ac.ae

Received 14 March 2019; Received in revised form 14 June 2019; Accepted 18 June 2019

\begin{abstract}
Aims: The investigation aimed to examine the crude oil-contaminated soil Streptomyces flora and study their capability to grow on diesel fuel as a sole carbon source and their analysis for the presence of alkane hydroxylase gene (alkB) by PCR.

Methodology and results: A total of 17 Streptomyces isolates were recovered from hydrocarbon-contaminated soil samples on starch casein nitrate agar medium with the ability of 4 isolates to grow on diesel [0.1\% (v/v)] as assessed by agar plate diffusion method, enzymatic assay and dry weight measurements. The ability of the four isolates (JR2b, JR3a, JR5b, and JR6f) to grow on diesel was revealed by the colour change of the reaction mixture and showing a growth response by growing around diesel-containing wells with a percentage increase in the dry weight of 24.60, 26.23, 18.03, and 18.03 after 28 days of incubation as compared to zero time, respectively. Although the four isolates were capable to degrade diesel as indicated by the three assessment techniques, they did not show any PCR product.

Conclusion, significance and impact of study: The isolates that grew on diesel and showed no PCR product might not contain the alkB gene, which implies that alkB gene is not the only gene that is responsible for the degradation of alkanes.
\end{abstract}

Keywords: Degradation, diesel, soil, Streptomyces

\section{INTRODUCTION}

Biodegradation of petroleum hydrocarbons by soil microorganisms has been an area of interest for many years (Kok and Oldenhuis, 1989; Mukherji et al., 2004). Isolation and identification of microorganisms responsible for hydrocarbon biodegradation have long been recognized and a number of hydrocarbon-degrading bacteria, yeasts, fungi, and algae are therefore available (Beilen et al., 2003; Jonathan et al., 2003). Some reports indicated that Streptomyces flora could play a very important role in degradation of hydrocarbons (Radwan et al., 1998; Barabas et al., 2001). For instance, Aitken et al. (1998) isolated Streptomyces spp. from polycyclic aromatic hydrocarbons contaminated soil that have the ability to degrade phenanthrene. Later, Barabas and his colleagues (2001) have isolated 3 Streptomyces strains (S. griseoflavus, $S$. parvus, and $S$ plicatus) from the Kuwait Burgan oil field with the ability to utilize $n$ hexadecane, $n$-octadecane, kerosene, and crude oil as sole carbon and energy sources.

Bacterial degradation of alkane usually occurs through the sequential oxidation of one or both terminal methyl groups of the molecule, first to an alcohol, then to an aldehyde, and finally to a fatty acid (Marín et al., 2001). A simple and rapid method was developed by Saadoun (2002; 2004) and Saadoun et al. (2008a) to assess the potential of organisms to grow on alkanes by detection of alcohol-production as a result of such degradation.

Molecular assessment of the ability of Streptomyces to degrade hydrocarbons usually done by PCR through targeting presumably involved genes. Many targeted genes have been studied to assess the ability of bacteria to degrade hydrocarbon compounds. One of the most studied genes is alkB gene which codes for a membranebound monooxygenase or alkane hydroxylase that plays the first step in alkane degradation process (Belhaj et al., 2002). However, more attention was devoted to alkane hydroxylase genes as markers to predict the potential of different organisms for oil degradation (Maeng et al., 1996; Murrell et al., 2000; Hamamura et al., 2001; Maier et al., 2001; Padda et al., 2001; Pandey et al., 2001; lida et al., 2002; Sluis et al., 2002; Smits et al., 2002). Genes involved in alkane degradation from bacteria Acinetobacter, Burkholderia, Mycobacterium, Pseudomonas, Rhodococcus, and from yeasts (Candida and Yarrowia) were cloned and sequenced (Watkinson and Morgan, 1990). 
In Jordan few studies have been conducted on hydrocarbon-polluted environments. Saadoun (2002; 2004) have isolated different bacteria from soil contaminated with oil and showed their ability to degrade diesel and short chain alkanes. Later, Saadoun et al. (2008a) have isolated Streptomyces spp. from Safawi/Jordan soils contaminated with crude oil. This study aimed to examine the crude oil-contaminated soil Streptomyces flora and study their capability to grow on diesel fuel as a sole carbon source via enzymatic analysis and examine their content of the alkane hydroxylase gene (alkB) by PCR.

\section{MATERIALS AND METHODS}

\section{Location, sampling and sample processing}

This study describes the occurrence and recovery of streptomycetes in chronically oil-polluted soils of Jordan Refinery in the City of Zarqa/Jordan with a historic exposure to crude or fuel oil spills for more than 25 years.

Samples from Jordan Refinery were collected from four different sites contaminated with crude/fuel oil spills. A control sample was taken from the refinery area but away from all sites. After removing approximately $3 \mathrm{~cm}$ of the soil surface material, $\sim 220-950 \mathrm{~g}$ of soil were collected and placed in plastic bags and stored in the laboratory at $4 \pm 1{ }^{\circ} \mathrm{C}$ until use.

\section{Processing and characterization of the sample}

Collected soil samples were crushed thoroughly mixed and sieved through a $2 \mathrm{~mm}$ pore size mesh (Retsch, Haan, Germany) to get rid of large debris. The sieved soil was used for determination of color, $\mathrm{pH}$, total petroleum hydrocarbons, and soil moisture in addition to the isolation of Streptomyces.

\section{Soil $\mathrm{pH}$, moisture and total petroleum hydrocarbon} (TPH) measurements

Soil suspension was made by diluting the soil to a known volume of distilled water $(1: 2 \mathrm{w} / \mathrm{v})$ and the $\mathrm{pH}$ was measured using a regular $\mathrm{pH}$ meter at $25^{\circ} \mathrm{C}$ (Hanna, Italy). For moisture determination, one gram of each soil sample was dried at $65{ }^{\circ} \mathrm{C}$ in the oven (WTB Binder, Germany) and the difference in the weight of the sample before and after drying was considered as the moisture content. Total petroleum hydrocarbon (TPH) in these contaminated soil samples was determined by constitutive extraction of $10 \mathrm{~g}$ of soil with hexane, dichloromethane and chloroform (100 mL each). All of the three extracted portions were pooled and dried at room temperature by evaporation of solvent in a fume hood (CMS, Spain). After solvent evaporation the amount of residual TPH was determined gravimetrically (Williams et al., 1972).

\section{Treatment of soil samples and isolation technique}

Enumeration and isolation of Streptomyces spp. were performed as described by Saadoun et al. (2008b) to represent those that were able to grow on starch casein nitrate agar (SCNA) plates.

\section{Assay for diesel degradation}

Growth conditions of Streptomyces and their adaptation on diesel

Each Streptomyces isolate that was recovered from the contaminated soils was inoculated into $50 \mathrm{~mL}$ of adaptation broth $(0.1 \%$ yeast extract, $0.1 \%$ peptone and $0.1 \%(\mathrm{v} / \mathrm{v})$ diesel), then incubated at $28{ }^{\circ} \mathrm{C}$ with shaking at $100 \mathrm{rev} / \mathrm{min}$ for $24 \mathrm{~h}$. The whole mixture in each flask was centrifuged for $5 \mathrm{~min}$ at $4000 \mathrm{rev} / \mathrm{min}$ and the pellet was suspended in the same medium and incubated under the same conditions for $24 \mathrm{~h}$. The last step was repeated three times, followed by washing the cells three times with $0.1 \mathrm{~mol} / \mathrm{L}$ phosphate buffer, $\mathrm{pH}$ 7.5. The pellets were finally suspended in a small volume $(5 \mathrm{~mL})$ of phosphate buffer and stored until used.

\section{Growth on diesel}

Growth of diesel-adapted Streptomyces was determined by the hole-plate diffusion method as previously described by Saadoun (2002) and Saadoun et al. (2008a) and evaluated at 7-day intervals by measuring the dry weight of cells $/ \mathrm{mL}$ of the cell suspension. Briefly, $20 \mu \mathrm{L}$ of the diesel-adapted Streptomyces were inoculated into 50 $\mathrm{mL}$ mineral salts medium (MSM) (Leadbetter and Foster, 1958) supplemented with $0.05 \%(\mathrm{v} / \mathrm{v})$ filter-sterilized diesel and incubated in water bath shaker (100 rev/min) for 28 days at $28{ }^{\circ} \mathrm{C}$. Dry weight was performed after placing $20 \mathrm{~mL}$ of the final bacterial cell suspension in preweighed aluminum tares in the oven for $12 \mathrm{~h}$ at $65^{\circ} \mathrm{C}$ before weighing.

\section{Enzymatic assay for diesel degradation}

Biodegradation of diesel was assayed according to the method of Jacobs et al. (1983) and as described by Saadoun (2002) and Saadoun et al. (2008a). Change in the color was compared with four controls. The first control contained no diesel (substrate), the second contained no $\mathrm{NAD}^{+}$and the third contained no cells. A fourth control consisted of heating the cells for $10 \mathrm{~min}$ at $90{ }^{\circ} \mathrm{C}$. The reaction was followed for $24 \mathrm{~h}$ and examined after 1, 2, 6, 12 and $24 \mathrm{~h}$.

\section{PCR study}

\section{Growth conditions}

All Streptomyces isolates that showed diesel degradation potential were cultured on Oxoid tryptic soy broth (TSB) 
(Hopowood et al., 1985) (30 g/L) at $28{ }^{\circ} \mathrm{C}$ with shaking at $140 \mathrm{rev} / \mathrm{min}$ for $48 \mathrm{~h}$. Purity of the cultures was confirmed by plating $0.1 \mathrm{~mL}$ from the broth on starch casein nitrate agar (SCNA) (Küster Williams, 1964) plates and incubated at $28^{\circ} \mathrm{C}$ for $72 \mathrm{~h}$.

\section{Extraction of genomic DNA from pure Streptomyces isolates}

Genomic DNA extraction was conducted using Wizard Genomic DNA Purification Kit (Promega, USA). Approximately $40 \mathrm{mg}$ (wet weight) mycelia were used in case of Streptomyces isolates, whereas one $\mathrm{mL}$ of an overnight broth growth was used in case of other bacteria. All DNA manipulation, handling and PCR work was conducted using DNase, RNase-Free barrier tips (Promega, USA).

\section{Quantitation of the extracted DNA and estimation of its purity}

The isolated DNA was checked for purity and quantitated spectrophotometrically (Sambrook et al., 1989). In each extraction group one sample (selected randomly) was extracted twice and was used in the estimation process. One sample $(50 \mu \mathrm{L})$ was diluted in $950 \mu \mathrm{L}$ Tris EDTA (TE) buffer and measured at 260 and $280 \mathrm{~nm}$ wavelengths (Genesys 2, Milton Roy, USA). The readings at $260 \mathrm{~nm}$ were used to calculate the DNA concentration in the original sample, where $1 \mathrm{OD}$ corresponds to $50 \mu \mathrm{g} / \mathrm{mL}$ of double-stranded DNA. The ratio between the readings at $260 \mathrm{~nm}$ and $280 \mathrm{~nm}\left(\mathrm{OD}_{260} / \mathrm{OD}_{280}\right)$ was used to estimate the purity of the DNA.

Design of primer sets for detection of alkane hydroxlyase gene (alkB)

The alkane hydroxylase gene (alkB) sequence of seven bacterial strains were obtained from GenBank and subjected to multiple alignments. Highly homologous regions were selected to design PCR primer set (Kohno et al., 2002). Two primers (Operon Technologies, USA) were used in the PCR study and as described before by Saadoun et al. (2008a). These primers were ALK-F: 5'TCGAGCACAACCGCGGCCACCA-3' and ALK-R: 5' CCGTAGTGCTCGACGTAGTT-3'.

\section{PCR amplification}

Amplification reactions were performed in volumes of 25 $\mu \mathrm{L}$ containing $12.5 \mu \mathrm{L}$ of master mix (Promega, USA), 1.5 $\mu \mathrm{L}$ forward primer, $1.5 \mu \mathrm{L}$ reverse primer, $8.5 \mu \mathrm{L}$ nuclease free water and $1 \mu \mathrm{L}$ of template DNA. PCR amplification was carried out in $0.2 \mathrm{~mL}$ thin walled, nucleases free water PCR tubes (Treff lab, Switzerland) using iCycler theromocycler (Bio-Rad, USA) programmed as followed: initial denaturizing step at $95{ }^{\circ} \mathrm{C}$ for 2 min followed by 30 cycles with denaturation at $94{ }^{\circ} \mathrm{C}$ for $60 \mathrm{sec}$, annealing at $40{ }^{\circ} \mathrm{C}$ for $30 \mathrm{sec}$, and extension at $72{ }^{\circ} \mathrm{C}$ for $30 \mathrm{sec}$, final extension at $40{ }^{\circ} \mathrm{C}$ for $3 \mathrm{~min}$. After that, the tubes were held at $4{ }^{\circ} \mathrm{C}$ for direct use or stored at $-20{ }^{\circ} \mathrm{C}$ for later use.

\section{Electrophoresis and photography}

Electrophoresis was carried out in $2 \%$ agarose (Promega, USA) gels in $1 \times$ TBE buffer at $100 \mathrm{~V}$ for $1.5 \mathrm{~h}$. The size of the PCR products was estimated using 100 bp DNA ladder (Promega, USA) and detected on the agarose gel by staining with ethidium bromide (EB) (Acros Organic, USA) at $0.5 \mu \mathrm{L} / \mathrm{mL}$ final concentration. Gels were viewed and documented using Gel Doc (Bio-Rad, USA).

\section{Characterization of Streptomyces isolates}

Streptomyces isolates with the positive potential to grow on diesel were characterized morphologically and physiologically according to the International Streptomyces project (ISP) (Shirling and Gottlieb, 1966) and as described by as described by Saadoun et al. (2008b).

\section{RESULTS}

\section{Characterization of soil samples}

The collected samples were characterized in terms of color, $\mathrm{pH}$ and moisture. The color of the samples ranged from light brown to black while $\mathrm{pH}$ ranged from 6.04-6.92 and moisture content ranged from 2.4 to $6.0 \%$ (Table 1 ). Total petroleum hydrocarbons (TPH) were measured for all the samples and were found between 75 and $142 \mathrm{mg} / \mathrm{g}$ of soil (Table 1). As a control, unpolluted soil sample was evaluated for color, TPH and moisture. The samples showed a light brown color, contained $45 \mathrm{mg} / \mathrm{g}$ TPH and a relatively lower moisture content of $6.78 \%$.

Occurrence, count and color diversity of Streptomyces

Streptomyces population in the polluted soils varied between $2 \times 10^{4}$ and $5 \times 10^{4}$ C.F.U./g (Table 1). However, this count in the unpolluted soils was $2 \times 10^{4}$ C.F.U./g (Table 1). Control soil sample which was taken from apparently non-polluted area showed slightly similar counts with an average of $2 \times 10^{4}$ C.F.U./g dry soil (Table 1).

\section{Assay for diesel degradation}

\section{Physical appearance}

Results demonstrated the ability of four Streptomyces isolates to grow on diesel when compared to the control well in the same plate that contains sterile distilled water only (Figure 1). 


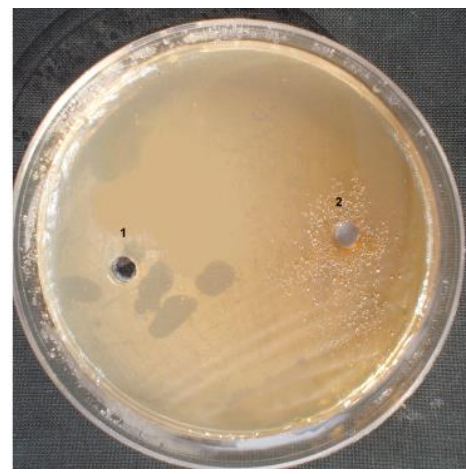

Figure 1: Growth response of Streptomyces isolates on diesel as indicated by physical appearance/ growth response of isolate No. JR6f in well 2 , well 1 contained sterile distilled water.

\section{Growth on diesel}

Growth on diesel was evaluated by measuring the dry weight of Steptomyces after the incubation period. Figure 2 shows the growth response of JR2b, JR3a, JR5b, and JR6f Streptomyces isolates on diesel fuel as indicated by the increase in the dry weight with a percentage increase of $24.60,26.23,18.03$, and 18.03 after 28 days of incubation as compared to zero time, respectively. However, by using this technique, we were unable to determine which isolate had the most ability to grow on diesel. Nevertheless, by estimating the dry weight of the cells we were able to determine which isolate have the most growth ability during the different intervals of incubation. It is worth noticing that degradation of diesel does not appear to be linear during all the time intervals.

\section{Enzymatic assay}

Table 2 shows that four of the tested active isolates were able to degrade diesel as indicated by color change from blue to yellow. All of the tested isolates were able to change the color of 2, 6-dichlorophenolindophnol (DCPIP) from blue color to yellow after $6 \mathrm{~h}$ of incubation. The four isolates performed similarly in degradation with no differences observed between them as indicated by the color change from blue to yellow-green in the first $2 \mathrm{~h}$ of incubation and then to yellow after $6 \mathrm{~h}$. The ability of Streptomyces to degrade diesel enzymatically was tested by either the removal of NAD+ from the reaction mixture (control 2) or heating the cells for $10 \mathrm{~min}$ at $90^{\circ} \mathrm{C}$ (control 4) with the subsequent inability of the isolate to perform degradation as indicated by the no change in the final color of the reaction mixture. Results of control 2 and control 4 experiments clearly show that the color of the reaction mixtures for all tested isolates did not change to yellow and they remain green at 6,12 , and $24 \mathrm{~h}$.
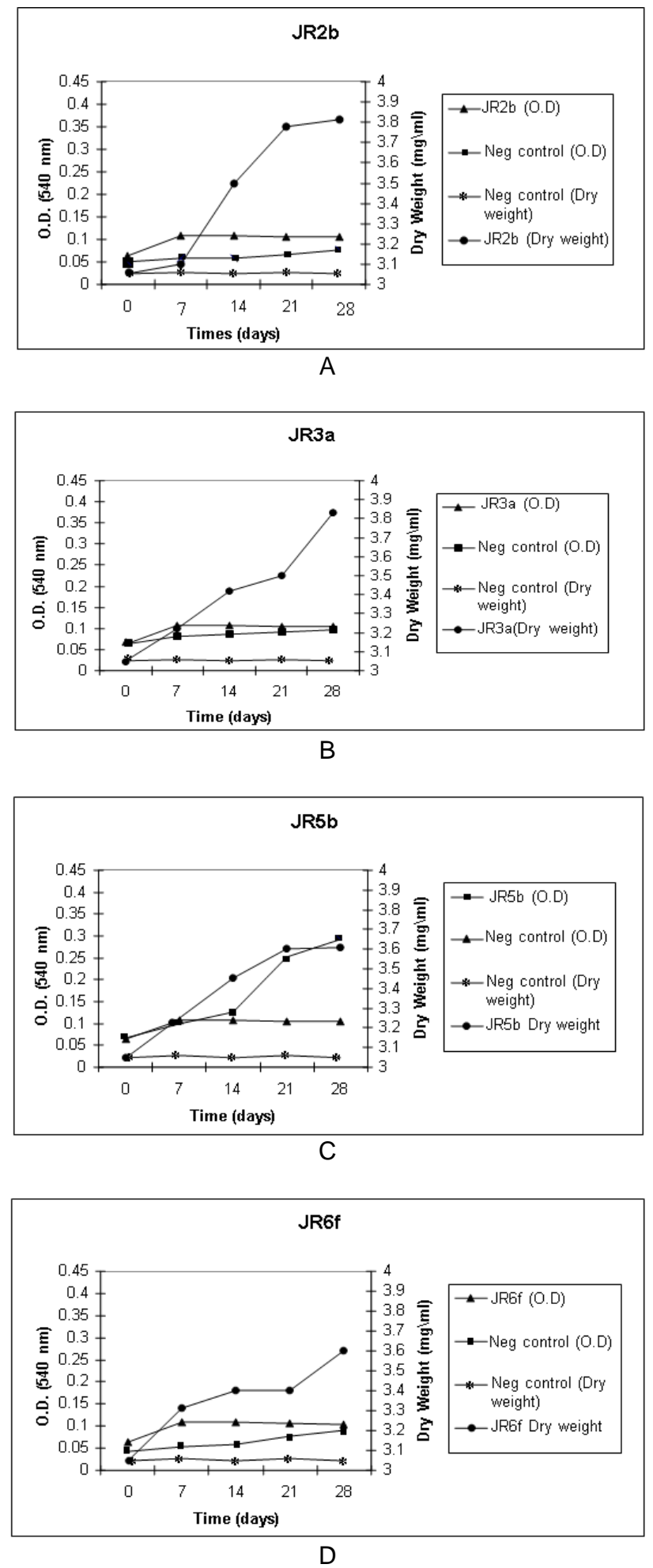

Figure 2: Dry weight $(\mathrm{mg} / \mathrm{mL})$ measurements and O.D. readings at $540 \mathrm{~nm}$ for the isolates JR2b (a); JR3a (b); JR5b (c); JR6f (d). 


\section{Detection of alkB gene sequence in Streptomyces isolates by PCR}

Genomic DNA was extracted using commercial DNA isolation kit. The extracted DNA was of a good quality as being tested by agarose gel electrophoresis. The extracted DNA is intact, clean and free of RNA (data not shown).

\section{PCR study for catabolic alkB gene}

Figure 3 shows the PCR products for four isolates (JR2b, JR3a, JR5b, and JR6f) which grew around dieselcontaining wells. All isolates (JR2b, JR3a, JR5b, and JR6f) did not show any PCR product although they were able to grow on diesel.

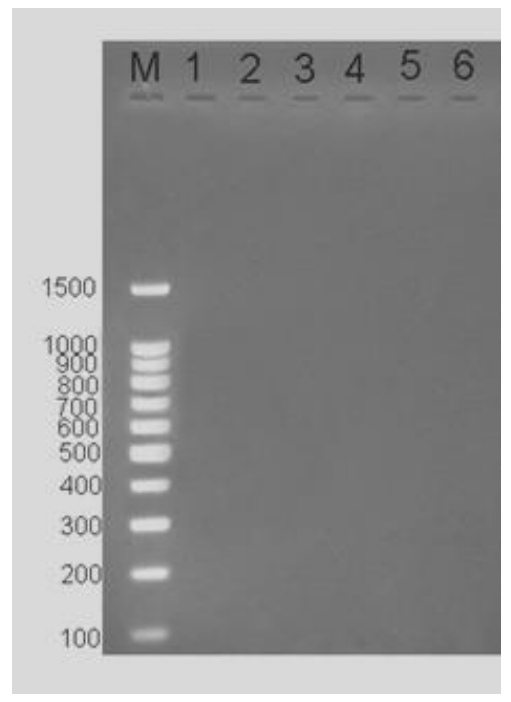

Figure 3: Agarose gel (2\%) electrophoresis of PCR amplification of alkane hydroxylase genes from Streptomyces isolates with Alk primer. Lane M: molecular weight marker $100 \mathrm{bp}$, lane 1: (negative control no PCR products), lane 2: negative control (no DNA template), lane 3: JR2b, lane 4: JR3a, lane 5: JR5b, lane 6: JR6f.

\section{Isolation and characterization of Streptomyces isolates}

A total of 17 different Streptomyces-like colonies were recovered from the polluted soils (Table 1 ). Results of dilution series and plate count of the samples that harbored the Streptomyces isolates revealed an average Streptomyces count ranged between $2 \times 10^{4}$ and $5 \times 10^{4}$ colony forming unit (CFU) /g dry soil (Table 1). The colony morphology of the Streptomyces isolates on starch casein nitrate agar plates (SCNA) after 10 days of incubation at $27^{\circ} \mathrm{C}$ indicated that they were small $(1-10 \mathrm{~mm}$ diameter), discrete and leathery, initially relatively with smooth surface but later developed a weft of aerial mycelium that appeared granular, powdery and velvety (data not shown).
Cultural and morphological characterization of these isolates resulted in their distribution into two color series (Table 1). The isolates JR3a and JR2b showed the maximum growth on diesel after 28 days with a dry weight biomass of 3.80 and $3.85 \mathrm{mg} / \mathrm{mL}$, respectively (Figure $2 \mathrm{~A}$ and Figure 2B). However, both JR5b and JR6f isolates showed the minimum growth on diesel after 28 days with a dry weight biomass of $3.60 \mathrm{mg} / \mathrm{mL}$ (Figure 2C and Figure 2D). The isolates JR2b, JR3a, JR5b, and JR6f showed a considerable growth on diesel with the ability of JR5b and JR6f isolates to utilize all of the tested sugars except rhamnose.

Those isolates that were able to utilize diesel were further characterized (Table 3). These isolates are with either spiral, or flexuous, or biverticillus sporophore and were unable to produce soluble and melanin pigments. Two isolates (JR2b, JR3a, and JR5b) showed distinctive reverse side color. Sugar utilization test indicate that all of the isolates were able to utilize glucose, sucrose, and fructose Isolates JR5b and JR6f utilized all of the tested sugars except rhamnose.

\section{DISCUSSION}

The work presented here has successfully isolated five potential soil Streptomyces isolates from oil-contaminated soil and assessed for their ability to degrade diesel via measuring their growth response, enzymatic assay, in addition to PCR analysis of the alkane hydroxylase gene $(a l k B)$ that is usually linked to hydrocarbon degradation.

Streptomyces are widely known for their capabilities to degrade organic compounds and have shown a capability to degrade hydrocarbon compounds (Radwan et al., 1998; Barabas et al., 2001; Saadoun et al., 2008b). These degradation capabilities are important metabolic activities that deserve to be studied particularly if these organisms are able to grow in polluted soils.

All the $\mathrm{pH}$ and moisture content values are considered within the optimal range for microbial activities. The variation in the color, $\mathrm{pH}$ or the moisture could be due to differences in levels and types of organic matter as well as differences in precipitation rates and exposure to sun. On the other hand, the difference in TPH could be due to lower or no exposure to oil spills.

Hydrocarbons spilled on soil elevate levels of organic carbon and may either serve as substrates for microbial growth or prove toxic to microbial growth and activity (Bossert and Barth, 1984). In our study, low streptomycetes counts in soils from Jordan Refinery suggest the failure of these indigenous microorganisms to grow and adapt due to accumulation of TPH which could reach toxic levels due to the nature of the crude oil or fuel-oil and the plethora of toxic substances it contained. Control soil sample which was taken from apparently nonpolluted area showed slightly similar counts with an average of $2 \times 10^{4}$ C.F.U./g dry soil. As mentioned earlier, this variation could be due to higher concentration of pollutant and location of sampling. In addition, the occurrences of Streptomyces in different habitats are affected by many factors including $\mathrm{pH}$, temperatures, 
nutrients and moisture (El-Nakeeb and Lechevalier, 1963).

All of Streptomyces isolates were screened for their potential to grow on diesel fuel by the hole-plate diffusion method as described by Saadoun (2002) and Saadoun et al. (2008b) using mineral salt medium supplemented with diesel fuel $(0.1 \% \mathrm{v} / \mathrm{v})$ as carbon source. This method allowed direct determination of the ability of the recovered Streptomyces isolates to grow on diesel.

Table 1: Hydrocarbon-contaminated soil samples collected from Jordan Oil Refinery and their characters and Streptomyces content.

\begin{tabular}{|c|c|c|c|c|c|c|c|c|c|c|}
\hline \multirow{2}{*}{$\begin{array}{c}\text { Sample } \\
\text { No. }\end{array}$} & \multicolumn{5}{|c|}{ Soil sample characters } & \multicolumn{3}{|c|}{ Bacterial count } & \multicolumn{2}{|c|}{$\begin{array}{l}\text { Streptomyces } \\
\text { color diversity }\end{array}$} \\
\hline & Colour & $\begin{array}{l}\text { Weight } \\
\text { (kg) }\end{array}$ & $\begin{array}{c}\text { Moisture } \\
\%\end{array}$ & $\mathrm{pH}$ & $\begin{array}{l}\mathrm{TPH} \\
\mathrm{mg} / \mathrm{g}\end{array}$ & $\begin{array}{l}\text { Total count } \\
\text { CFU X10\%/g } \\
\text { soil }\end{array}$ & $\begin{array}{c}\text { Streptomyces } \\
\text { count } \\
\text { CFU X10 } / \mathrm{g} \text { soil }\end{array}$ & $\begin{array}{c}\% \text { of } \\
\text { Streptomyces/gm } \\
\text { soil }\end{array}$ & White & Grey \\
\hline JR 1 & Black & 0.765 & 2.4 & 6.04 & 117 & 0.34 & 2 & 5.88 & 1 & 1 \\
\hline JR 2 & Black & 0.700 & 3.8 & 6.72 & 99 & 0.22 & 5 & 22.73 & 5 & \\
\hline JR 3 & Black & 0.227 & 6.0 & 6.65 & 142 & 0.35 & 3 & 8.57 & 3 & \\
\hline JR:6 & $\begin{array}{l}\text { Light } \\
\text { brown }\end{array}$ & 0.221 & 3.6 & 6.92 & 75 & 0.64 & 5 & 7.81 & & 5 \\
\hline $\begin{array}{c}\text { JR } 5 \\
\text { (control) }\end{array}$ & $\begin{array}{l}\text { Light } \\
\text { brown }\end{array}$ & 0.309 & 2.2 & 6.78 & 45 & 0.79 & 2 & 2.53 & & 2 \\
\hline
\end{tabular}

Table 2: Action of different Streptomyces isolates on diesel fuel as indicated by color change ${ }^{a}$

\begin{tabular}{|c|c|c|c|c|c|}
\hline \multicolumn{6}{|c|}{ Streptomyces isolate } \\
\hline $\begin{array}{l}\text { Reaction } \\
\text { condition }\end{array}$ & $\begin{array}{c}\text { Time } \\
\text { (h) }\end{array}$ & JR2b & JR3a & JR5b & JR6f \\
\hline \multirow{5}{*}{$\begin{array}{c}+\mathrm{NAD}^{+} \\
29^{\circ} \mathrm{C}+\text { Diesel }\end{array}$} & 1 & $\mathrm{Y}-\mathrm{Gr}$ & $\mathrm{Y}-\mathrm{Gr}$ & $\mathrm{Y}-\mathrm{Gr}$ & $\mathrm{Y}-\mathrm{Gr}$ \\
\hline & 2 & $\mathrm{Y}-\mathrm{Gr}$ & $\mathrm{Y}-\mathrm{Gr}$ & $\mathrm{Y}-\mathrm{Gr}$ & Y-Gr \\
\hline & 6 & $\mathrm{Y}$ & $Y$ & Y & $Y$ \\
\hline & 12 & Y & Y & Y & $Y$ \\
\hline & 24 & Y & Y & $\mathrm{Y}$ & Y \\
\hline Result & & + & + & + & + \\
\hline \multirow{5}{*}{$29^{\circ} \mathrm{C}\left({ }^{- \text {Control }^{+}}\right)^{\mathrm{b}}$} & 1 & $\mathrm{Bl}$ & $\mathrm{Bl}$ & $\mathrm{Bl}$ & $\mathrm{Bl}$ \\
\hline & 2 & $\mathrm{Bl}$ & $\mathrm{Bl}$ & $\mathrm{Bl}$ & $\mathrm{BI}$ \\
\hline & 6 & $\mathrm{Gr}$ & $\mathrm{Gr}$ & Gr & Gr \\
\hline & 12 & $\mathrm{Gr}$ & $\mathrm{Gr}$ & $\mathrm{Gr}$ & $\mathrm{Gr}$ \\
\hline & 24 & $\mathrm{Gr}$ & $\mathrm{Gr}$ & $\mathrm{Gr}$ & $\mathrm{Gr}$ \\
\hline Result & & - & - & - & - \\
\hline \multirow{5}{*}{$90 \stackrel{+\mathrm{NAD}^{+}}{{ }^{\circ} \mathrm{C}(\text { Control } 4)}$} & 1 & $\mathrm{Bl}$ & $\mathrm{Bl}$ & $\mathrm{Bl}$ & $\mathrm{BI}$ \\
\hline & 2 & $\mathrm{Bl}$ & $\mathrm{Bl}$ & $\mathrm{Bl}$ & $\mathrm{Bl}$ \\
\hline & 6 & $\mathrm{Gr}$ & $\mathrm{Gr}$ & $\mathrm{Gr}$ & $\mathrm{Gr}$ \\
\hline & 12 & $\mathrm{Gr}$ & $\mathrm{Gr}$ & $\mathrm{Gr}$ & $\mathrm{Gr}$ \\
\hline & 24 & $\mathrm{Gr}$ & $\mathrm{Gr}$ & $\mathrm{Gr}$ & $\mathrm{Gr}$ \\
\hline Result & & - & - & - & - \\
\hline
\end{tabular}

${ }^{\mathrm{a} C}$ Color change from dark blue to other colors at different time interval by each Streptomyces isolate: $\mathrm{Y}=$ yellow; $\mathrm{Gr}=$ green $\mathrm{Bl}=$ blue.

bThe first control contained no diesel (substrate), the third contained no cells. Control 2: $\mathrm{NAD}^{+}$is removed from the reaction mixture, and control 4 cells were heated for 10 min at $90^{\circ} \mathrm{C}$

To further evaluate the ability of the isolates to degrade diesel, Streptomyces growth and utilization of diesel was enzymatically assayed following the procedure of Jacobs et al. (1983). A pre-adapting step for Streptomyces isolates to utilize diesel fuel was carried out before testing diesel oxidation was intended for the induction of mixed function oxygenases and other catabolic enzymes essential for biodegradation (Saadoun, 2002). The ability of Streptomyces to degrade diesel enzymatically was tested by either the removal of $\mathrm{NAD}^{+}$ from the reaction mixture or heating the cells for $10 \mathrm{~min}$ at
$90{ }^{\circ} \mathrm{C}$ with the subsequent inability of the isolate to perform degradation as indicated by the no change in the final color of the reaction mixture. These results appeared to be in accordance with previous results reporting the same enzymatic test on Pseudomonas strains (Saadoun, 2004) and Streptomyces strains (Saadoun et al., 2008b).

To test for the presence of alkB gene in the isolated Streptomyces a pair of primers were designed by multiple alignments of several sequences from all alkane hydroxylase genes registered in the Gene Bank. This allows the detection of the maximum number of alkane degrading bacteria. Alkane hydroxylase gene $(a l k B)$ is a very important gene that has been recorded in several actinomycetes linked to hydrocarbon degradation including Nocardia, Mycobacteria and Rhodococcus genera (El-Nakeeb and Lechevalier, 1963; Hopowood et al., 1985; Kohno et al., 2002), and Streptomyces spp. (Saadoun et al., 2008b). There were 16 alkane hydroxylase gene sequences in the data bank, and all were classified into 3 groups through phylogenetic analysis (Saul et al., 2005). Currently over 250 alkB gene homologues were found in diverse bacterial species in which a large portion of these genes was detected in oilcontaminated environments (Padda et al., 2001).

The five tested isolates that did not show any PCR product but were able to grow on diesel may be explained that the alkB gene is not the only gene that is responsible for the degradation of alkanes, and the isolates that grew on diesel and showed no PCR product might not contain the alkB gene or the product might be merely a none specific annealing and extension to the primers rather than specific amplification. On the other hand, it could be a similar but nonfunctional gene, thus, the isolates were not showing PCR band. The presence of alkB gene in Streptomyces isolates does not mean that they can degrade diesel as diesel contains many hydrocarbon components other than alkanes.

The results of the high occurrence of the white and grey series is in agreement with other studies by Saadoun 
Malays. J. Microbiol. Vol 15(6) 2019, pp. 480-487

DOI: http://dx.doi.org/10.21161/mjm.190400

Table 3: Characteristics of the Streptomyces isolates that grew on diesel.

\begin{tabular}{|c|c|c|c|c|c|c|c|c|c|c|c|}
\hline \multirow[t]{3}{*}{ Isolate No. } & \multirow{2}{*}{\multicolumn{5}{|c|}{ Macroscopic cultural characteristics }} & \multicolumn{6}{|c|}{ Utilization of carbon sources $^{d}$} \\
\hline & & & & & & I & $\mathrm{Ra}$ & $X$ & A & M & $\mathrm{Rh}$ \\
\hline & $\mathrm{AM}^{\mathrm{a}}$ & $\mathrm{SM}^{\mathrm{b}}$ & $\begin{array}{l}\text { Soluble } \\
\text { pigment }\end{array}$ & $\begin{array}{l}\text { Melanin } \\
\text { pigment }\end{array}$ & $\begin{array}{l}\text { Sporophore } \\
\text { morphology }\end{array}$ & & & & & & \\
\hline JR2b & Beige & + & - & - & $\mathrm{F}$ & - & + & - & + & - & + \\
\hline JR3a & Beige & + & - & - & $\mathrm{F}$ & + & + & + & - & + & - \\
\hline JR5b & Grey & + & - & - & BIV & + & - & + & + & + & + \\
\hline JR6f & Grey & - & - & - & $S$ & + & - & + & + & + & + \\
\hline
\end{tabular}

aAM: Aerial mycelium

bSM: Substrate mycelium; -: non-distinctive; +: distinctive

'Sporophore morphology: Flexuous (F), Biverticillus (BIV), and Spirales (S), )

${ }^{\mathrm{d}}$ All of the tested isolates were able to utilize glucose, sucrose, and frcuctose. I=Insitol, Ra=Raffinose,

$\mathrm{X}=$ Xylose, $\mathrm{A}=$ Arabinos, $\mathrm{M}=$ Mannose, and $\mathrm{Rh}=$ Rhamnose.

and Al-Momani (1997) and Saadon et al. (1999) which found that the grey and white color were the most frequent color series in Jordanian soils.

\section{CONCLUSION}

The study showed that Streptomyces flora does prevail in oil-contaminated soil with a potential to degrade diesel as assessed by different physical, chemical and molecular techniques. The presence of alkB gene in Streptomyces isolates does not mean that they can degrade diesel.

\section{ACKNOWLEDGEMENTS}

Deanship of Scientific Research at Jordan University of Science and Technology funded this research (Grant No. 123/2005). Appreciation is extended to University of Sharjah/UAE for administrative support.

\section{CONFLICT OF INTEREST}

The authors of this manuscript have declared no conflict of interest.

\section{REFERENCES}

Aitken, M. D., Stringfellow, W. T., Nagel, R. D. and Kazunga, C. (1998). Characteristics of phenanthrenedegrading bacteria isolated from soils contaminated with polycyclic aromatic hydro-carbons. Canadian Journal of Microbiology 44, 743-752.

Barabas, G. Y., Vargha, G., Szabo, I. M. and Penyige, A. (2001). n-Alkane uptake and utilization by Streptomyces strains. Antonie van Leeuwenhoek 79, 269-276.

Beilen, J. B., van, Li, Z., Duetz, W. A., Smits, T. H. M. and Witholt, B. (2003). Diversity of alkane hydroxylase systems in the environment. Oil Gas Science Technology 58, 427-440.

Belhaj, A., Desnoues, N. and Elmerich, C. (2002). Alkane biodegradation in Pseudomonas aeruginosa strains isolated from a polluted zone: Identification of
alkB and alkB-related genes. Research Microbiology 153, 339-344.

Bossert, I. and Bartha, R. (1984). The Fate of Fuel Spills in Soil Ecosystems. In: Petroleum Microbiology. Atlas, R. M. (ed.). Macmillan, New York, USA. pp. 435-473.

El-Nakeeb, M. A. and Lechevalier, H. A. (1963). Selective isolation of aerobic actinomycetes. Applied Microbiology 11, 75-77.

Hamamura, N., Yeager, C. M. and Arp, D. J. (2001). Two distinct monooxygenase for alkane oxidation in Nocardioides sp. Strain CF8. Applied and Environmental Microbiology 67, 4992-4998.

Hopowood, D. A., Bibb, M. J., Chater, K. F. and Kieser, T. (1985). Genetic Manipulation of Streptomyces: A Laboratory Manual. John Innes Foundation, Norwich. United Kingdom. pp. 79-80.

lida, T., Sumita, T., Ohta, A. and Takagi, M. (2002). The cytochrome P450 ALK multigene family of an n-alkane assimilating yeast, Yarrowia lipolytica: cloning and characterization of genes coding for new CYP52 family members. Yeast 16, 1077-1087.

Jacobs, C. J., Prior, B. A. and Dekock, M. J. (1983). A Rapid screening method to detect ethanol production by microorganisms. Journal of Microbiological Methods 1, 339-342.

Jonathan, D., Van Hamme, A. S. and Owen, P. W. (2003). Recent advances in petroleum microbiology. Microbiology Molecular Biology Review 67, 503-549.

Kohno, T., Sugimoto, Y., Sei, K. and Mori, K. (2002). Design of PCR primers and gene probes for general detection of alkane-degrading bacteria. Microbes and Environment 17, 114-121.

Kok, M. and Oldenhuis, R. (1989). The Pseudomonas oleovorans alkane hydroxylase gene. Journal of Biological Chemistry 264, 5435-5441.

Küster, E. and Williams, S. (1964). Selection media for the isolation of streptomycetes. Nature 202, 928-929.

Leadbetter, E. R. and Foster, J. W. (1958). Studies of some methane utilizing bacteria. Archive Microbiology Review 30, 91-118.

Maier, T., Foerster, H. H., Asperger, O. and Hahn, U. (2001). Molecular characterization of the $56-\mathrm{kDa}$ 
CYP153 from Acinetobacter sp. EB104. Biochemistry Biophysics Research Community 286, 652-658.

Murrell, C. J., Gilbert, B. and McDonald, I. R. (2000). Molecular biology and regulation of methane monooxygenase. Archive Microbiology 173, 325-332.

Maeng, J. H., Sakai, Y., Tani, Y. and Kato, N. (1996). Isolation and characterization of a novel oxygenase that catalyzes the first step of $n$-alkaneoxidation in Acinetobacter sp. strain M-1. Journal of Bacteriology 178, 3695-3700.

Marín, M. M., Smits, T. H., van Beilen, J. B., and Rojo, F. (2001). The alkane hydroxylase gene of Burkholderia cepacia RR10 is under catabolite repression control. Journal of Bacteriology 183, 42024209.

Mukherji, S., Jagadevan, S., Mohapatra, G. and Vijay, A. (2004). Biodegradation of diesel oil by an Arabian Sea sediment culture isolated from the vicinity of an oil field. Bioresource Technology 95, 281-286.

Padda, R. S., Pandey, K. K., Kaul, S. and Nair, V. D. (2001). A novel gene encoding a $54 \mathrm{kDa}$ polypeptie is essential for butane utilization by Pseudomonas $\mathrm{sp}$. IMT37. Microbiology 147, 2479-2491.

Pandey, K. K., Mayilray, S. and Chakrabarti, T. (2001). Pseudomonas indica sp. a novel butane utilizing species. International Journal of Systematic Evolutionary Microbiology 52, 1559-1567.

Radwan, S. S., Barabás, G. Y., Sorkhoh, N. A. and Damjanovich, S. (1998). Hydrocarbon uptake by Streptomyces. FEMS Microbiology Letters 169, 87-94.

Saadoun, I. (2002). Isolation and characterization of bacteria from crude petroleum oil contaminated soil and their potential to degrade diesel fuel. Journal of Basic Microbiology 42, 420-428.

Saadoun, I. and AL-Momani, F. (1997). Studies on soil streptomycetes from Jordan. Actinomycetes 8, 42-48.

Saadoun, I., AL-Momani, F., Malkawi, H. and Mohammad, M. J. (1999). Isolation, identification and analysis of antibacterial activity of soil streptomycetes isolated from north Jordan. Microbios 100, 41-46.

Saadoun, I. (2004). Recovery of Pseudomonas spp. From chronically fuel-polluted soils in Jordan and the study of their capability to degrade short chain alkanes. World Journal of Microbiology and Biotechnology 20, 43-46.

Saadoun, I., Alawawdeh, M., Jaradat, Z. and Ababneh, Q. (2008a). Growth of Streptomyces spp. from hydrocarbon-polluted soil on diesel and their analysis for the presence of alkane hydroxylase gene (alkB) by PCR. World Journal of Microbiology and Biotechnology 24, 2191-2198.

Saadoun, I., Wahiby, L., Ababneh, Q. and Jaradat, Z. (2008b). Recovery of soil streptomycetes from arid habitats in Jordan and their potential to inhibit multidrug resistant Pseudomonas aeruginosa pathogens. World Journal of Microbiology and Biotechnology 24, 157-162.

Sambrook, J., Fritsch, E. F. and Maniatis, T. (1989). Molecular Cloning: A Laboratory Manual. Cold Spring Harbor, New York, USA. $2^{\text {nd }}$ edn. pp. 150-478.
Saul, D. J., Aislabie, J. M., Brown, C. E. and Harris, L. (2005). Hydrocarbon contamination changes the bacterial diversity of soil from around Scott Base, Antarctica. FEMS Microbiology and Ecology 53, 141155.

Shirling, E. B. and Gottlieb, D. (1966). Methods for characterization of streptomycetes species. International Journal of Systematic Bacteriology 16, 313-340.

Sluis, M. K., Sayaverda, Soto, L. A. and Arp, D. J. (2002). Molecular analysis of the soluble butane monooxygenase from "Pseudomonas butanovora". Microbiology 148, 3617-3629.

Smits, T. H. M., Balada, S. B., Witholt, B. and van Beilen, J. B. (2002). Functional analysis of alkane hydroxylases from Gram negative and Gram positive bacteria. Journal of Bacteriology 184, 1733-1742.

Watkinson, R. J. and Morgan, P. (1990). Physiology of aliphatic hydrocarbon-degrading microorganisms. Biodegradation 1, 79-92.

Williams, S. T., Shameemullah, M., Watson, E. T. and Mayfield, C. I. (1972). Studies on the ecology of actinomycetes in soil VI. The influence of moisture tension on growth and survival. Soil Biology and Biochemistry 4, 215-225. 